\title{
Chemical Vapor Deposition of Tungsten Oxide
}

Rein U. Kirss* and Lamartine Meda

Department of Chemistry, Northeastern University, Boston, MA 02115, USA

Crystalline and amorphous thin films of tungsten(VI) oxide can be prepared by chemical vapor deposition using a variety of volatile precursors below $500{ }^{\circ} \mathrm{C}$. Deposition parameters for preparation of $\mathrm{WO}_{3}$ films from tungsten hexacarbonyl $\left[\mathrm{W}(\mathrm{CO})_{6}\right]$, tungsten hexafluoride $\left(\mathrm{WF}_{6}\right)$, tungsten ethoxides $\left[\mathrm{W}(\mathrm{OEt})_{x}, x=5,6\right]$ and tetra(allyl)tungsten $\left[\mathrm{W}\left(\eta^{3}-\mathrm{C}_{3} \mathrm{H}_{5}\right)_{4}\right]$ are summarized. The electrochromic behavior of these films is comparable with that observed for $\mathrm{WO}_{3}$ films prepared by evaporation, sputtering and electrodeposition. (C) 1998 John Wiley \& Sons, Ltd.

Appl. Organometal. Chem. 12, 155-160 (1998)

Keywords: tungsten trioxide; electrochromism; thin films; chemical vapor deposition (CVD)

Received 5 December 1996; accepted 3 March 1997

\section{INTRODUCTION}

The electrochromic behavior of tungsten(VI) oxide makes $\mathrm{WO}_{3}$ an attractive material for electronic devices. ${ }^{1}$ Partial reduction of colorless $\mathrm{WO}_{3}$ generates an intense blue color assigned to intervalence charge transfer in partially reduced $\mathrm{WO}_{3}$. The electrochemical reduction of tungsten(VI) to tungsten $(\mathrm{V})$ is accompanied by uptake of cations (e.g. $\mathrm{H}^{+}, \mathrm{Li}^{+}$etc.) to maintain electrical neutrality, and is reversible. Applications for thin films of $\mathrm{WO}_{3}$ and other electrochromic materials include 'smart windows', electrochromic displays and other electronic devices. ${ }^{1}$

Both amorphous and crystalline tungsten oxide films have been prepared. The electrochromic properties are strongly dependent on the preparative method and conditions. For example, sol-gelderived $\mathrm{WO}_{3}$ films do not exhibit electrochromism unless they are annealed or laser-fired. ${ }^{2}$ The early

*Correspondence to: Rein U. Kirss, Department of Chemistry, Northeastern University, Boston, MA 02115, USA. literature contains several reports of electro-optically inactive $\mathrm{WO}_{3}$ films prepared by sputtering, evaporation or spray methods, ${ }^{3}$ although later work has yielded electrochromic $\mathrm{WO}_{3}$ films by these methods. ${ }^{1}$ No attempt is made here to review the literature pertaining to $\mathrm{WO}_{3}$ films prepared by these methods.

The present review focuses on CVD of amorphous and crystalline tungsten oxide films, including thermal CVD, plasma-enhanced CVD (PECVD) and photo-assisted CVD (PACVD). The principle advantage of chemical vapor deposition of electronic materials over other methods is in step coverage, the absence of radiation damage, throughput and the possibility for selective growth. ${ }^{4}$ For example, CVD of $\mathrm{WO}_{3}$ occurs at temperatures significantly below those for evaporation $\left(1300^{\circ} \mathrm{C}\right) .^{5}$

\section{FILM GROWTH}

CVD of $\mathrm{WO}_{3}$ from tungsten hexafluoride $\left(\mathrm{WF}_{6}\right)$ and tungsten carbonyl $\left[\mathrm{W}(\mathrm{CO})_{6}\right]$ precursors has received the greatest attention. Both compounds are volatile and commercially available. Tungsten trioxide films have also been prepared from tungsten alkoxides, $\mathrm{W}\left(\mathrm{OC}_{2} \mathrm{H}_{5}\right)_{n}(n=5,6)$. Recently, we have prepared thin films of $\mathrm{WO}_{3}$ from tetra(allyl)tungsten, $\mathrm{W}\left(\eta^{3}-\mathrm{C}_{3} \mathrm{H}_{5}\right)_{4}$. A summary of deposition conditions and film composition is to be found in Table 1.

\section{TUNGSTEN HEXAFLUORIDE}

Tungsten hexafluoride, $\mathrm{WF}_{6}$, is widely applied as a precursor for the deposition of tungsten metal and has been used in the deposition of tungsten oxides. ${ }^{4,6}$ Deposition of pure tungsten from $\mathrm{WF}_{6}$ under $\mathrm{H}_{2}$ or $\mathrm{SiH}_{4}$ results in inclusion of some crystalline $\mathrm{W}_{20} \mathrm{O}_{58}$ and possibly other tungsten oxide impurities in body-centered cubic (bcc) tungsten films. ${ }^{7}$

Tungsten oxide films have been intentionally 
Table 1 Comparison of film deposition conditions and composition

\begin{tabular}{|c|c|c|c|c|c|c|}
\hline Precursor & $\begin{array}{c}\text { Growth temp. } \\
\left({ }^{\circ} \mathrm{C}\right)\end{array}$ & $\begin{array}{c}\text { Growth rate } \\
(\mathrm{nm} / \mathrm{min})\end{array}$ & Film thickness & Structure & $\mathrm{O}: \mathrm{W}$ ratio & Ref. \\
\hline $\mathrm{W}(\mathrm{CO})_{6} / \mathrm{O}_{2}$ anneal & 500 & $-{ }^{\mathrm{a}}$ & $185-1500$ & Crystalline & $3: 1$ & $15-17$ \\
\hline $\mathrm{W}(\mathrm{CO})_{6} / \mathrm{O}_{2} / \mathrm{O}_{2}$ anneal & 500 & $-^{\mathrm{a}}$ & $185-1500$ & Crystalline & $3.12: 1$ & $15-17$ \\
\hline $\mathrm{W}(\mathrm{CO})_{6} /$ air & $200-400$ & $30-40$ & 250 & Amorphous & $1.83: 1$ & $21-24$ \\
\hline $\mathrm{W}(\mathrm{CO})_{6} / \mathrm{air} / h v$ & $150-250$ & $200-400$ & 250 & Amorphous & $2.92: 1$ & 25 \\
\hline $\mathrm{W}(\mathrm{CO})_{6} / \mathrm{O}_{2}(\mathrm{PECVD})$ & 60 & $8-9$ & & Amorphous & & 10 \\
\hline $\mathrm{WF}_{6} / \mathrm{O}_{2}(\mathrm{PECVD})$ & $50-60$ & 28 & $150-650$ & Amorphous & $3.7: 1$ & 10 \\
\hline $\mathrm{WF}_{6} / \mathrm{H} \cdot / \mathrm{air}$ & $50-60$ & $18-24$ & 250 & & $\approx 3: 1$ & 11 \\
\hline $\mathrm{W}(\mathrm{OEt})_{x}(X=5,6)$ & $100-300$ & $0.75-30$ & & Amorphous & $2.6-3.2: 1$ & 6 \\
\hline $\mathrm{W}(\text { allyl })_{4} / \mathrm{O}_{2}$ anneal & $250-450$ & $-{ }^{a}$ & 250 & Crystalline & & 32 \\
\hline
\end{tabular}

${ }^{a}$ For these samples, the oxide is generated by oxygen annealing of a previously prepared $\mathrm{WO}_{x} \mathrm{C}_{y}$ film, so direct comparisons of growth rates are meaningless.

deposited from $\mathrm{WF}_{6}$ using pure oxygen or air. A growth rate of $28 \mathrm{~nm} \mathrm{~min}{ }^{-1}$ was reported for an amorphous $\mathrm{WO}_{3}$ grown from $\mathrm{WF}_{6}$ in air using plasma-enhanced CVD. ${ }^{8,9}$ Films ranging from 150 to $650 \mathrm{~nm}$ in thickness were deposited at low substrate temperature $\left(50-60{ }^{\circ} \mathrm{C}\right)$ on indium tin oxide-coated sodalime glass substrates. Analysis of fluorine-free films prepared in this fashion gave an $\mathrm{O} / \mathrm{W}$ ratio of $3.7: 1$ by Auger spectroscopy.

$\mathrm{WO}_{3}$ films have also been grown on a wide variety of substrates from $\mathrm{WF}_{6}$ and room air in the presence of radiofrequency-generated hydrogen atoms. ${ }^{10}$ Growth rates ranged from 18 to $24 \mathrm{~nm}$ $\min ^{-1}$ producing amorphous, producing films $250 \mathrm{~nm}$ thick with a 3:1 ratio of oxygen to tungsten. Fluorine impurities were not detected in these films, but fluorine-doped $\mathrm{WO}_{3}$ films can be prepared from pyrolysis of $\mathrm{WF}_{6}$ in the presence of difluoroethane and isopropanol as the fluorine and oxygen sources. ${ }^{11}$

\section{TUNGSTEN HEXACARBONYL}

Thermal decomposition of $\mathrm{W}(\mathrm{CO})_{6}$ above $400{ }^{\circ} \mathrm{C}$ in the absence of oxygen produces tungsten metal contaminated with carbon and oxygen. ${ }^{12-14}$ Asdeposited films of this type have been referred to as 'reflective tungsten' to distinguish them from 'black tungsten' films deposited from $\mathrm{W}(\mathrm{CO})_{6}$ in the presence of oxygen under the same conditions. X-ray diffraction (XRD) and Reflection High Energy Electron Diffraction (RHEED) data on black tungsten films were consistent with $\mathrm{W}_{18} \mathrm{O}_{49}$ and either tetragonal $\mathrm{WO}_{2.9}$ or monoclinic $\mathrm{W}_{20} \mathrm{O}_{58 \cdot}{ }^{11} \mathrm{X}$-ray photo-electron spectroscopy (XPS) confirmed the presence of tungsten(V) and

(C) 1998 John Wiley \& Sons, Ltd.
tungsten(VI) in 'black tungsten' films. Films were successfully deposited on quartz, aluminum, and tin oxide-coated glass.

XRD, RHEED and XPS data for 'black' or 'reflective' tungsten films annealed in oxygen between 400 and $600{ }^{\circ} \mathrm{C}$ were consistent with formation of polycrystalline $\mathrm{WO}_{3}$ containing monoclinic $\mathrm{WO}_{3}{ }^{12}$ The oxygen tungsten ratio in the transparent films ranged from $2.77: 1$ to $3.57: 1$, depending on annealing temperature and the partial pressure of oxygen. ${ }^{15}$ Oxidation rates ranged from 1 to $2 \mathrm{~nm} \mathrm{~min}$ min $^{-1}$, producing films from 185 to $1500 \mathrm{~nm}$ thick. ${ }^{16}$

Decomposition of $\mathrm{W}(\mathrm{CO})_{6}$ in air between 200 and $400{ }^{\circ} \mathrm{C}$ produces amorphous, transparent $\mathrm{WO}_{3}$ films with $\mathrm{O} / \mathrm{W} \approx 1.83: 1$. The films contain metal and grow at a rate of $30-40 \mathrm{~nm} \mathrm{~min}^{-1} \cdot{ }^{18-24}$ Growth temperatures were further reduced to $\approx 150{ }^{\circ} \mathrm{C}$ and growth rates $\left(200-400 \mathrm{~nm} \mathrm{~min}^{-1}\right)$ were significantly enhanced using photo-assisted CVD (PACVD). ${ }^{21-24}$ The oxygen/tungsten ratio in the PACVD films $(\approx 250 \mathrm{~nm}$ thick $)$ increased to $\approx 2.92: 1$. Growth rates for plasma-enhanced CVD using $\mathrm{W}(\mathrm{CO})_{6}$ in $\mathrm{O}_{2}$ at $60^{\circ} \mathrm{C}$ are in the range of 8$9 \mathrm{~nm} \mathrm{~min}{ }^{-1}$.

\section{TUNGSTEN ALKOXIDES}

Tungsten alkoxides are attractive precursors for CVD of tungsten oxide thin films avoiding, in principle, the need for oxygen annealing steps. There is one report of CVD of tungsten oxide using tungsten ethoxides, $\mathrm{W}\left(\mathrm{OC}_{2} \mathrm{H}_{5}\right)_{n}(n=5,6) .{ }^{25}$ Pentakis(ethoxy)tungsten is a volatile liquid and hexakis(ethoxy)tungsten is a solid. Amorphous, adherent films of $\mathrm{WO}_{3}(\mathrm{O}: \mathrm{W}$ ratio 2.7-3.2:1) were 
Table 2 Summary of electrochromic properties of $\mathrm{CVD} \mathrm{WO}_{3}$ films

\begin{tabular}{|c|c|c|c|c|c|c|}
\hline \multirow[b]{2}{*}{ Deposition method } & \multirow[b]{2}{*}{ Precursor } & \multirow[b]{2}{*}{ Structure } & \multirow[b]{2}{*}{$\mathrm{n}^{\mathrm{a}}\left(\mathrm{cm}^{2} \mathrm{C}^{-1}\right)$} & \multicolumn{2}{|c|}{ Response time } & \multirow[b]{2}{*}{ Ref. } \\
\hline & & & & Coloration & Bleaching & \\
\hline \multirow[t]{5}{*}{ Thermal CVD } & $\mathrm{W}(\mathrm{CO})_{6}$ & Amorphous & 230 & $30 \mathrm{~s}$ & $30 \mathrm{~min}$ & $18-20$ \\
\hline & $\mathrm{W}(\mathrm{CO})_{6}$ & Crystalline & $40^{\mathrm{b}}$ & $0.330 \mathrm{~s}$ & $13 \mathrm{~s}$ & 13,14 \\
\hline & & & 25.5 & $60-120 \mathrm{~s}$ & & $13-16$ \\
\hline & $\mathrm{W}(\mathrm{OEt})_{x}$ & Amorphous & n.r. ${ }^{\mathrm{c}}$ & n.r. & n.r. & 25 \\
\hline & $\mathrm{W}(\text { allyl })_{4}$ & Crystalline & n.r. & n.r. & n.r. & 31 \\
\hline PACVD & $\mathrm{W}(\mathrm{CO})_{6}$ & Amorphous & 222 & $2 \min$ & $10 \mathrm{~min}$ & $21-24$ \\
\hline PECVD & $\mathrm{WF}_{6}$ & Amorphous & 100 & $30 \mathrm{~s}$ & & 8,9 \\
\hline
\end{tabular}

${ }^{\mathrm{a}}$ In $1 \mathrm{M} \mathrm{LiClO}_{4}$ or $\mathrm{LiBF}_{4}$ unless otherwise noted. ${ }^{\mathrm{b}} 1 \mathrm{M} \mathrm{H}_{2} \mathrm{SO}_{4}$. c n.r., not reported.

grown on quartz, sodalime glass, indium tin oxidecoated glass and silicon. Growth rates ranged from 0.75 to $30 \mathrm{~nm} \mathrm{~min}{ }^{-1}$ over the temperature range $100-300{ }^{\circ} \mathrm{C}$. Carbon contamination was below 2 atom $\%$. Powdery blue films were deposited above $350{ }^{\circ} \mathrm{C}$.

\section{ORGANOMETALLIC TUNGSTEN COMPOUNDS}

A number of organometallic tungsten compounds have been investigated as precursors for the CVD of tungsten metal, ${ }^{6}$ including bis(cyclopentadienyl)tungsten dihydride, $\left[\left(\eta^{5}-\mathrm{Cp}\right)_{2} \mathrm{WH}_{2}\right]^{26}$ tris(methylvinylketone)tungsten, $\left[\mathrm{W}\left(\mathrm{C}_{4} \mathrm{H}_{6} \mathrm{O}\right)_{3}\right],{ }^{27}$ tris(butadiene)tungsten $\left[\mathrm{W}\left(\mathrm{C}_{4} \mathrm{H}_{8}\right)_{3}\right]^{27}$ and tetra(allyl)tungsten, $\left[\mathrm{W}\left(\eta_{3}-\mathrm{C}_{3} \mathrm{H}_{5}\right)_{4}{ }^{28}\right.$ Tungsten carbide films have been grown from $\mathrm{CpW}(\mathrm{CO})_{3} \mathrm{H}, \mathrm{Cp} * \mathrm{~W}(\mathrm{CO})_{3} \mathrm{H}$, $\left(\mathrm{C}_{7} \mathrm{H}_{8}\right) \mathrm{W}(\mathrm{CO})_{3}, \quad\left(\mathrm{C}_{8} \mathrm{H}_{12} \mathrm{~W}(\mathrm{CO})_{3}\right.$, toluene$\mathrm{W}(\mathrm{CO})_{3}{ }^{29}$ and $\mathrm{Me}_{3} \mathrm{C}\left(\mathrm{CH}_{2}\right)_{2} \mathrm{~W} \equiv \mathrm{CCMe}_{3} .{ }^{30}$ Deposition of tungsten oxide films from these precursors has not been reported.

Dark, reflective films (250 nm thick) deposited from $\mathrm{W}\left(\eta^{3}-\mathrm{C}_{3} \mathrm{H}_{5}\right)_{4}$ under vacuum contain both carbon and oxygen $\left(\mathrm{WC}_{x} \mathrm{O}_{y} ; X \approx 1, Y \approx 0.25\right.$ by XPS $){ }^{28}$ These amorphous films turn blue in air over a period of days to weeks depending on the film thickness $^{31}$ Annealing under oxygen at $400^{\circ} \mathrm{C}$ produces transparent, colorless films containing crystalline $\mathrm{WO}_{3}$ (by XRD) but retaining significant amounts of carbon (17 atom\%).

\section{OPTICAL AND ELECTROCHROMIC PROPERTIES}

The quality of CVD-prepared tungsten oxide films for application in electrochromic devices can be assessed through measurement of several parameters, including coloration efficiency, response time and cycle life ${ }^{1,32}$ The electrochromic properties of CVD $\mathrm{WO}_{3}$ films are summarized in Table 2 . The color change is described by Eq. [1] and in Fig. 1:

$$
\begin{aligned}
& \mathrm{WO}_{3}+\mathrm{x} \mathrm{M}^{+}+\mathrm{x} \mathrm{e}^{-} \rightarrow \underset{\mathrm{x}}{\mathrm{M}_{(1-x)}} \mathrm{W}_{x} \mathrm{O}_{3} \\
& \text { colorless } \\
& \text { bleached } \\
& \text { colored }
\end{aligned}
$$$$
\mathrm{M}^{+}=\mathrm{H}^{+}, \mathrm{Li}^{+}
$$

\section{COLORATION EFFICIENCY}

The coloration efficiency, $\eta$, of an electrochromic thin film is determined from Eq. [2], where $\alpha$ is the absorption coefficient, $d$ the film thickness, $\Delta A$ the change in optical absorption and $Q$ the charge

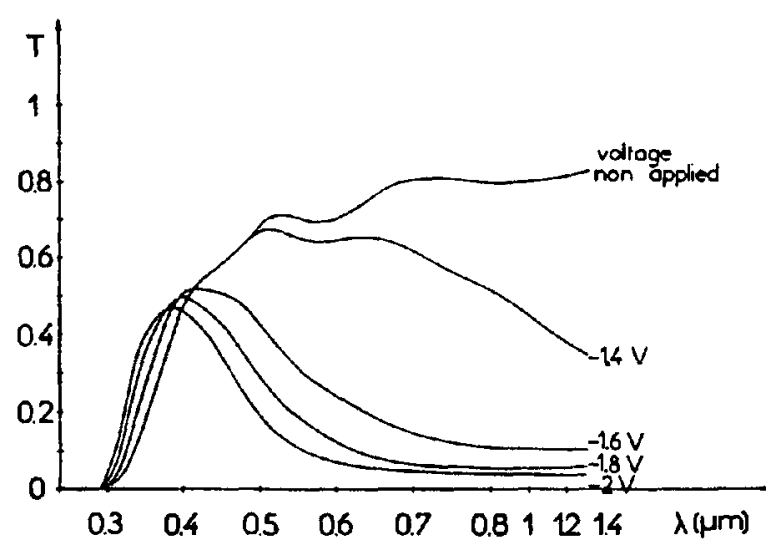

Figure $1 \mathrm{UV}-\mathrm{Vis}$ spectrum of $\mathrm{WO}_{3}$ as a function of applied voltage. $^{13}$ 
injected per unit area. A large coloration efficiency is desirable for electronic display and window applications. The coloration efficiency depends on the film growth conditions and on the precursor.

$$
\eta \frac{(\alpha d)}{Q}=\frac{\Delta A}{Q}
$$

Amorphous $\mathrm{WO}_{3}$ thin films prepared by PACVD from $\mathrm{W}(\mathrm{CO})_{6}$ can have coloration efficiencies similar to those prepared by thermal CVD. Crystalline $\mathrm{WO}_{3}$ films prepared by thermal CVD from $\mathrm{W}(\mathrm{CO})_{6}$, however, have $\eta$ values more than five times less than the amorphous films. Amorphous $\mathrm{WO}_{3}$ films prepared by plasma-enhanced CVD using $\mathrm{WF}_{6}$ had coloration efficiencies of $100 \mathrm{~cm}^{2}$ $\mathrm{C}^{-1}$, between the values for amorphous and crystalline films prepared using $\mathrm{W}(\mathrm{CO})_{6}$. There are no data on coloration efficiencies of films deposited from tungsten alkoxides or other organometallic precursors. Coloration efficiency is also dependent on the electrolyte, i.e. $\mathrm{LiClO}_{4}$ or $\mathrm{H}_{2} \mathrm{SO}_{4}$.

\section{RESPONSE TIME}

The elapsed time for conversion of $\mathrm{WO}_{3}$ from a colored, reduced form to the 'bleached', oxidized form (or vice versa) is called the response time. A response time of the order of seconds or minutes is acceptable for electrochromic windows but much faster response times are required for displays. A direct comparison of response time values is difficult as different criteria are employed in the measurement. Electrochromic $\mathrm{WO}_{3}$ films prepared by CVD generally color faster than they are bleached. The shortest coloration times are of the order of 0.33 seconds to achieve measureable decreases in transmission (increases in absorption) in the visible region of the spectrum. ${ }^{13,14}$ The bleaching times show a far greater range, requiring up to $30 \mathrm{~min}$ for complete decoloration in some cases.

\section{CYCLE LIFE}

The cycle life of an electrochromic film reflects the number of coloration/bleaching cycles a particular film can tolerate before a noticeable loss or failure in performance is observed. Longer cycle lives are

(C) 1998 John Wiley \& Sons, Ltd. desirable for any device applications. Limited data on cycle life for CVD $\mathrm{WO}_{3}$ films have been reported, but they appear to be stable for tens of cycles.

\section{DISCUSSION}

Tungsten trioxide films have been prepared by chemical vapor deposition using a variety of tungsten precursors. By comparison with other deposition methods, CVD-prepared films have similar electrical and optical characteristics.

Electrochemically deposited $\mathrm{WO}_{3}$ films with response times of $\approx 0.1 \mathrm{~s}$ have been reported. ${ }^{33}$ $\mathrm{WO}_{3}$ films sputtered from the metal oxide have response times measured in seconds, but recent results $^{34}$ show a strong dependence of the electrochromic properties on preparation methods. $\mathrm{WO}_{3}$ films sputtered from the metal in an oxidizing atmosphere have longer response times, ranging from less than $30 \mathrm{~s}$ for colorizing to more than $1 \mathrm{~min}$ for bleaching. These data are similar to the range of results observed for CVD films using $\mathrm{W}(\mathrm{CO})_{6}$ as a precursor. Sol-gel-derived films have coloration times of $120 \mathrm{~s}^{3}$ There is some evidence that response time is a function of film density. ${ }^{32}$ The electrochemically deposited films with the fastest response times have densities between 4.8 and $5.0 \mathrm{~g} \mathrm{~cm}^{-3}$ compared with $5.3-6.5 \mathrm{~g} \mathrm{~cm}^{-3}$ for vacuum-evaporated films and $5.62 \mathrm{~g} \mathrm{~cm}^{-3}$ for CVD films prepared using tungsten hexacarbonyl. ${ }^{13-17}$ Bulk $\mathrm{WO}_{3}$ has a density of $7.16 \mathrm{~g} \mathrm{~cm}^{-3}$.

The coloration efficiencies for $\mathrm{CVD} \mathrm{WO}_{3}$ films are generally comparable and are sometimes better than films prepared by other deposition techniques. For example, amorphous $\mathrm{WO}_{3}$ films prepared by thermal evaporation have $\eta$ values ranging from 76 to $115 \mathrm{~cm}^{2} \mathrm{C}^{-1}$ compared with a value of $222 \mathrm{~cm}^{2}$ $\mathrm{C}^{-1}$ for amorphous CVD films. Polycrystalline films grown by dc (direct current) or radiofrequency sputtering have $\eta$ values ranging from 42 to $115 \mathrm{~cm}^{2} \mathrm{C}^{1}$, compared to $\eta$ values between 26 and $41 \mathrm{~cm}^{2} \mathrm{C}^{-1}$ for crystalline $\mathrm{WO}_{3}$ films prepared by CVD.

Our knowledge of the effect of the precursor on electrochromic properties is hampered by an absence of data on coloration efficiency and response times for all the precursors. Data on $\mathrm{WF}_{6}$ and $\mathrm{W}(\mathrm{CO})_{6}$ indicate similar electrochromic behavior for films grown from either precursor (Table 2). The electrochromic properties, however, 


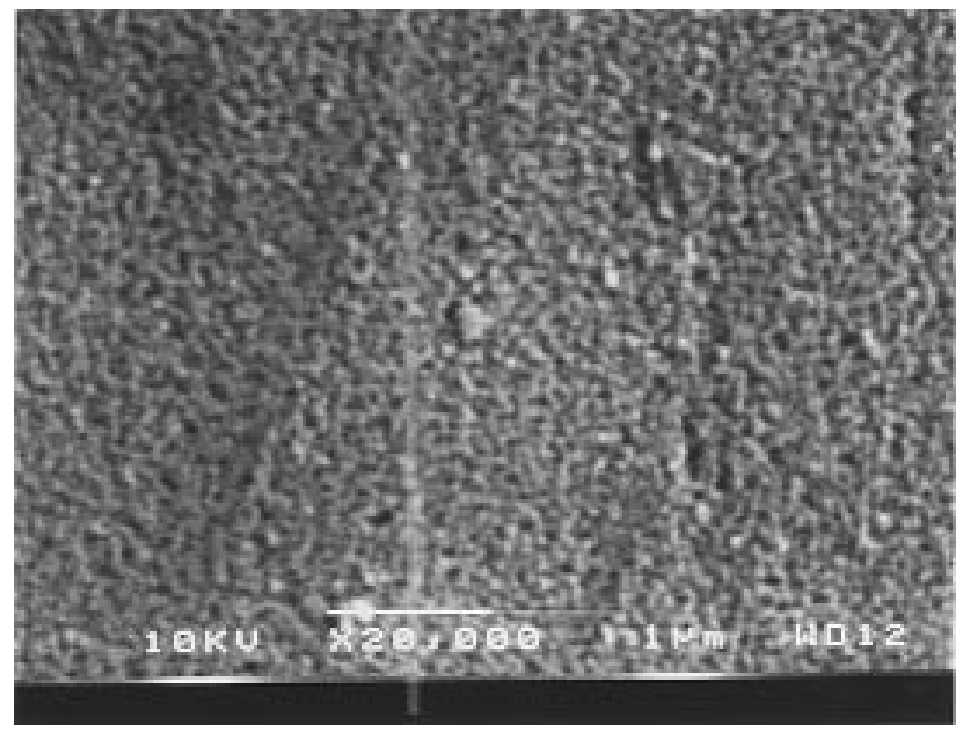

Figure 2 SEM of $\mathrm{WO}_{3}$ film grown from $\mathrm{W}\left(\eta^{3}-\mathrm{C}_{3} \mathrm{H}_{5}\right)_{4}$.

are clearly dependent on growth conditions and film crystallinity.

Smooth, adherent and uniform films have been grown using all four precursors cited in Table 2 (Fig. 2). The microstructure of the films is dependent on substrate and deposition conditions. MOCVD using $\mathrm{W}(\mathrm{CO})_{6}$ on borosilicate glass produced smooth featureless films, whereas films deposited on fluorine-doped tin oxide were coarse and dull in appearance. ${ }^{25}$ Changing deposition conditions for $\mathrm{W}(\mathrm{OEt})_{5}$ and $\mathrm{WF}_{6}$ results in powdery, non-adherent films. ${ }^{6,10}$

\section{CONCLUSIONS}

The deposition of electrochromic tungsten(VI) oxide films by CVD has received little attention in comparison with other thin-film growth methods. A survey of the literature suggests that the coloration efficiency of $\mathrm{CVD} \mathrm{WO}_{3}$ films is comparable with that of those prepared by evaporation, electrodeposition or sputtering. Response times are adequate for application in 'smart window' technology. Unfortunately, the films with the best coloration efficiency and deposited at the fastest growth rates do not coincide with the shortest response time. Investigations of alternative precursors to $\mathrm{WO}_{3}$ which combine rapid growth with short response times at high color efficiencies appear to be warranted although widespread application of CVD $\mathrm{WO}_{3}$ films in large-area devices such as window coatings may not be competitive with sol-gel or electrodeposition techniques.

\section{REFERENCES}

1. P. M. S. Monk, R. J. Mortimer and D. R. Rosseinsky, Electrochromism, VCH, New York, 1995, and references therein.

2. D. J. Taylor, J. P. Cronin, L. F. Allard Jr and D. P. Birnies III, Chem. Mater. 8, 1396 (1996).

3. H. R. Zeller and H. U. Beyler, Appl. Phys. 13, 231 (1977).

4. M. L. Green and R. A. Levy, J. Metals 37, 63 (1985).

5. R. J. Colton, A. M. Guzman and J. W. Rabalais, Acct. Chem. Res. 11, 170 (1978).

6. A. A. Zinn, Chemical vapor deposition of tungsten metal. In: The Chemistry of Chemical Vapor Deposition, Kodas T. T., and Hampden-Smith M. S. (eds), VCH, New York, 1995.

7. M. L. A. Dass, S. Sivirams and B. Tracy, Mater Res. Soc. Symp. Proc. 168, 185 (1990).

8. C. E. Tracy and D. K. Benson, J. Vac. Sci. Technol. A 4, 2377 (1986).

9. D. K. Benson, C. E. Tracy and J. S. E. M. Svensson, Proc. SPIE 823, 72 (1987).

10. W. W. Lee and R. R. Reeves, Mater Res. Soc. Symp. Proc. 250, 137 (1992).

11. J. W. Proscia, C. H. Winter, G. P. Reck and G. G. Wen, Mater Res. Soc. Symp. Proc. 283, 933 (1993).

Appl. Organometal. Chem. 12, 155-160 (1998) 
12. B. Yous, S. Robin, A. Donnadieu, G. Dufour, C. Maillot, H. Roulet and C. Senemaud, Mater. Res. Bull. 19, 1349 (1984).

13. D. Davazoglou, A. Donnadieu and O. Bohnke, Solar Energy Mater. 16, 55 (1987).

14. A. Donnadieu, D. Davazoglou and A. Abdellaoui, Thin Solid Films 164, 333 (1988).

15. D. Davazoglou, A. Donnadieu, R. Fourcade, A. HugotLegoff, P. Delichere and A. Perez, Revue. Phys. Appl. 23, 265 (1988).

16. D. Davazoglou and A. Donnadieu, Thin Solid Films 147, 131 (1987)

17. O. Bohnke, C. Bohnke, D. Davazoglou and A. Donnadieu, J. Appl. Electrochem. 18, 447 (1988).

18. T. Maruyama and S. Arai, J. Electrochem. Soc. 141, 1021 (1994).

19. D. S. Gogova, K. A. Gesheva and G. I. Stoyanov, Proc. SPIE - Int. Soc. Opt. Eng. 2255 (1994).

20. K. A. Gesheva, G. Stoyanov and D. Gogova, Mater Res. Soc. Symp. Proc. 415, 155 (1996).

21. T. Maruyama and T. Kanagawa, J. Electrochem. Soc. 141, 2435 (1994).

22. Z. Cao and J. R. Owen, Thin Solid Films 271, 69 (1995).
23. A. D. Kuypers, C. I. M. A. Spee, J. L. Linden, G. Kischner, J. F. Forsyth and A. Mackor, Surf. Coat. Technol. 74-75, 1033 (1995).

24. T. Maruyama, JP 0726384 (1995).

25. U. Riaz, Thin Solid Films 235, 15 (1993).

26. B. Niemer, A. A. Zinn, W. K. Stovall, P. E. Gee, R. F. Hicks and H. D. Kaesz, Appl. Phys. Lett. 61, 1793 (1992).

27. R. U. Kirss, D. G. Gordon and P. S. Kirlin, Mater. Res. Soc. Symp. Proc. 282, 275 (1993).

28. J. Chen, R. B. Hallock and R. U. Kirss, Mater Res. Soc. Symp. Proc. 250, 303 (1992).

29. K. K. Lai and H. H. Lamb, Chem. Mater. 7, 2292 (1995). and references therein.

30. Z. Xue, K. G. Caulton and M. H. Chisholm, Chem. Mater. 3, 384 (1991).

31. L. J. Meda and R. U. Kirss, Abstr. 210th ACS National Meeting, Chicago, IL, 20-24, Aug. 1995, INOR No. 226.

32. K. Bange and T. Gambke, Adv. Mater. 2, 10 (1990).

33. P. K. Shen, K. Y. Chen and A. C. C. Tseung, J. Electrochem. Soc. 141, 1758 (1994).

34. R. A. Batchelor, M. S. Burdis and J. R. Siddle, J. Electrochem. Soc. 143, 1050 (1996). 